\title{
El patrocinio intraclerical en el Antiguo Régimen: curias y familias episcopales de los arzobispos de Toledo (1755-1823)
}

\author{
Andoni Artola Renedo- Universidad del País Vasco,
}

España

\section{Resumen}

Este trabajo propone la aplicación del análisis exploratorio de redes para el estudio del reclutamiento de la jerarquía eclesiástica, particularmente el episcopado, en la España del Antiguo Régimen. Se parte de la identificación de los actores que colaboraban con el arzobispo de Toledo en su servicio personal o en su acción de gobierno, se exponen sus trayectorias personales y se muestran, en conclusión, procesos de cooptación en el episcopado español entre los siglos XVIII y XIX.

Palabras clave: Iglesia Católica, Episcopado, Reclutamiento, Red Social.

\begin{abstract}
This paper proposes the utilization of social network analysis in the research of upper clerical recruitment in Spain during the Old Regime. For that purpose, social actors that collaborated with the archbishop in his personal service or in the goverment of the archbishopric have been identified, their subsequent careers have been described and, finally, a process of self-recruitment of the Spanish episcopate has been detected.
\end{abstract}

Key Words: Catholic Church, Episcopate, Recruitment, Social Network.

La Iglesia del Antiguo Régimen tenía notables paralelismos con la sociedad política, en particular en su organización interna. En la cúspide se situaba el romano pontífice, cabeza de una monarquía electiva que perdura hasta nuestros días. Desde aquí, se extendía hacia todo el mundo católico la red jerárquica clerical que llegaba hasta los fieles en las parroquias: administración pontificia, episcopado, administración diocesana, ministerio parroquial, con diversos niveles intermedios. Existen notables trabajos de conjunto que dan una idea global de esta compleja "administración de la salvación" en la Edad Moderna². No obstante, hace falta urgentemente trasladar a este ámbito planteamientos conceptuales y metodológicos

\footnotetext{
1 La realización de este trabajo ha sido posible gracias a una beca predoctoral concedida por la Universidad del País Vasco.

2 Para España, ver Morgado (2000), Barrio (2010). Localizado en un obispado, pero muy completo, Irigoyen López (2005). Trabajos centrados en diócesis concretas permiten conocer mejor el complejo mundo de la administración eclesiástica: véanse, a este respecto, Pérez Muñoz (1992) o Candau Chacón (1993). Una excelente visión global para Francia en Plongeron (1974), en que el autor delinea con bastante precisión los diferentes aspectos, tanto jerárquicos como sacramentales, del ámbito eclesiástico. En la misma línea, MacManners (1999).
} 
REDES- Revista hispana para el análisis de redes sociales

Vol.21,\#6, Diciembre 2011

http://revista-redes.rediris.es

hace tiempo asumidos en otros campos (Morales, 1984; Castellano, Dedieu, LópezCordón, 2000). El descubrimiento y descripción rigurosa del entramado institucional eclesiástico, el conocimiento de las funciones de cada elemento en el sistema global de la administración y las formas de reclutamiento de los empleados en tales funciones deben ser, a mi juicio, los pilares sobre los que se asiente cualquier análisis de la sociedad eclesiástica en el Antiguo Régimen.

El estudio de la administración eclesiástica en todos sus niveles jerárquicos está conduciendo a la detección de dinámicas intraclericales de largo alcance explicativo. Ha sido la historiografía francesa la que más ha trabajado estos aspectos (Péronnet, 1977; Boudon, 1996). En nuestro caso, el análisis exploratorio de las redes administrativas del episcopado español ha permitido observar un fenómeno que cambia notablemente la idea que hasta ahora se tenía sobre el reclutamiento de los mitrados. Como se pretende demostrar en este trabajo, la experiencia en el gobierno de una diócesis bajo la supervisión del prelado suponía una fase clave de una carrera episcopal. Las curias episcopales componían tejidos relacionales en cuyo seno se daba cita parte de la siguiente generación rectora de la Iglesia española. El valor historiográfico de esta perspectiva reside, por lo tanto, en la transferencia del centro de interés primario en el estudio del reclutamiento episcopal, desde el Patronato regio y el derecho de presentación de las mitras por el monarca, a las relaciones internas, propias, del estamento clerical - en sus más altos niveles jerárquicos. Esto supone cambiar absolutamente de horizonte explicativo y, a través del análisis de las trayectorias previas de los obispos y las relaciones establecidas al filo de sus carreras, entrar en las lógicas internas al clero que animaban el reclutamiento de la jerarquía eclesiástica. En consecuencia, se verá cómo la elección de la más alta jerarquía eclesiástica por la corona, estaba grandemente constreñida a ciertos actores que ya los prelados de la generación precedente habían señalado como candidatos a la mitra.

Para mostrar esta realidad, me centraré en el caso del arzobispado de Toledo durante los pontificados de Luis Fernández de Córdoba (1775-1771), Francisco Antonio Lorenzana (1772-1800) y Luis Borbón Vallabriga (1800-1823). Trataré en un primer apartado del marco general de la administración eclesiástica en el Antiguo Régimen y de sus estructuras diocesanas; en el segundo, expongo el contexto relacional en el que se forjan las redes del arzobispo; y en el tercero y último, analizo las carreras posteriores de los hombres de la curia. En lo metodológico, el análisis ha pasado por el vaciado intensivo de datos de documentación de archivo y de las Guías 
Eclesiásticas (publicadas desde 1787$)^{3}$ sobre las curias eclesiásticas y las familias episcopales de los prelados. El siguiente paso ha sido el conocimiento e identificación de los actores que ocupaban los puestos administrativos y las relaciones entre ellos. La ordenación y clasificación de la información en una base de datos relacional ha permitido exportar los datos a un paquete de análisis de redes sociales (Pajek), en que se observan los resultados globales y el alcance del fenómeno.

\section{El gobierno de la Iglesia católica en el Antiguo Régimen: el arzobispado de Toledo y su estructura administrativa}

La administración de la estructura eclesiástica tiene por finalidad última proveer los medios necesarios para la salvación de las almas, promover la disciplina y la dirección de las conciencias. La lectura de cualquiera de las Constituciones sinodales redactadas tras el Concilio de Trento puede probar esto ${ }^{4}$. Como el rey gobierna a sus siervos para obtener y mantener la paz y la prosperidad en sus dominios, el clero tiene como misión poner a los fieles en el camino trazado por Jesucristo para la salvación.

Para esta misión salvífica, la Iglesia se organizaba en una jerarquía que tenía al Papa en su vértice. El estamento clerical, porción de especialistas que la misma Iglesia separaba de la sociedad para su gobierno, era depositario y transmisor oficial de una tradición religiosa, que tenía el deber misional de hacer cumplir y perdurar. El clero se caracterizaba por su apariencia externa, su inmunidad, y por su formación doctrinal y académica, que le distinguían del laicado. En el organigrama jerárquico clerical, cualquiera de las posiciones que se podían ocupar tenía una función específica que complementaba las demás, en la función colectiva del clero de dirigir la sociedad eclesiástica (Berardi, 1791: II, 2-15).

No es este el lugar de extenderse en esta cuestión particular, sino dar una idea del marco en el que se desarrollan las relaciones entre los distintos componentes de la administración eclesiástica, de forma que no se pierda de vista el amplio espectro de vínculos que conectan a los actores en los diferentes niveles jerárquicos del clero católico.

\footnotetext{
${ }^{3}$ En adelante, se citarán como (Guía: año).

${ }^{4}$ Un ejemplo entre muchos, y por ser el que se va a tratar aquí, Quiroga (1583). Consulta libre en http://books.google.es/.
} 
El arzobispado de Toledo era en el siglo XVIII el más importante de España. Varios son los índices en los que destacaba para ocupar esta preeminente posición: sus rentas, valoradas en $320.000^{5}$ reales, muy superiores a las de la media de las diócesis españolas (Hermann, 1986: 161-162); los 62400 kilómetros cuadrados de extensión que abarcaba, y que comprendían la práctica totalidad de las actuales provincias de Toledo, Ciudad Real y Madrid, buena parte de las de Guadalajara y Cuenca, algunas áreas en las de Albacete, Cáceres y Badajoz, así como enclaves en Avila, Jaén y Granada, además de las plazas africanas de Orán y Mazalquivir; y su primacía formal, reconocida por la autoridad política - rey- y espiritual -papa- desde la Edad Media, que imprimía a la dignidad arzobispal un sello de exclusividad y prioridad sobre las demás mitras españolas (Gonzálvez, 2006: 419-426). Así, desde el pontificado de Pedro González de Mendoza (1472-1495), todos los arzobispos de Toledo, excepto cuatro, alcanzaron la púrpura cardenalicia, que venía a confirmar no sólo su preeminencia, sino su papel de portavoz del episcopado español y de intermediario de la Iglesia en España con la corte de Roma ${ }^{6}$.

Tanto la extensión territorial del arzobispado, como las frecuentes ausencias de los arzobispos, contribuyeron a la configuración de un aparato administrativo de amplias dimensiones. En jerarquía descendente se organizaba con el arzobispo en la cúspide, por debajo del cual estaba el Consejo de Gobernación, ente creado en el siglo XIII y cuya configuración definitiva tuvo lugar con la ordenanza del arzobispo García de Loaysa en 1598. Estaba compuesto de un presidente y cuatro oidores, que, al comienzo, sólo contaban con atribuciones en lo temporal, si bien con el tiempo las consiguieron en lo espiritual. Contaba con su respectivo tribunal de apelación, y podía ver causas de naturaleza bien distinta: procesos sobre capellanías, beneficios, patronazgos, licencias de non residendo, enajenación de bienes de fábricas o parroquias, causas criminales de clérigos por ausencias, aprobación de notarios, licencias para exponer el Santísimo y para representaciones teatrales en iglesias, así como causas criminales contra canónigos y dignidades de la catedral, entre otras (Rodríguez González, 2002: 128).

Dos obispos auxiliares, propuestos por el arzobispo y nombrados por el rey, administraban el sacramento de la confirmación y conferían las órdenes sagradas en Madrid y en Toledo. Dos vicarios generales, uno en Alcalá de Henares y el otro en

\footnotetext{
${ }^{5}$ Según la visita ad limina del arzobispo Luis Fernández de Córdoba (Fernández Collado, 2002: 124).

6 El primer arzobispo creado cardenal residiendo en su diócesis fue don Pedro González de Mendoza (1472-1495). Los arzobispos no cardenales fueron: Alonso Fonseca (1523-1534), Bartolomé Carranza Miranda (1558-1576), García Loaisa Girón (1598-1599), y Francisco Valero Losa (1715-1720).
} 
REDES- Revista hispana para el análisis de redes sociales

Vol.21,\#6, Diciembre 2011

http://revista-redes.rediris.es

Toledo, con sus respectivos tribunales, recibían la jurisdicción delegada del prelado, en grado considerado por éste, en todo el arzobispado. Generalmente recibían también el oficio de provisor, con lo que, en la unión de ambos cargos, administraban la justicia eclesiástica civil y criminal. El de Toledo debía cumplir el requisito de ser canónigo de la catedral, y presidía los tribunales sinodales y los concursos a curatos.

En un nivel inferior actuaban los vicarios llamados "foráneos", también con jurisdicción delegada del arzobispo, aunque sólo para una demarcación concreta de la diócesis. En el siglo XVIII la de Toledo llegó a contar con nueve vicarías foráneas ${ }^{7}$, a saber: Madrid, Alcaraz, Alcazar de San Juan, Cazorla, Ciudad Real, Huéscar, Orán, Puente del Arzobispo, Talavera de la Reina, Puente del arzobispo y Orán. El vicario foráneo se encargaba de supervisar las iglesias y el clero del territorio que le era asignado, y conocía en primera instancia las causas eclesiásticas criminales y civiles que se abrían en su distrito (Rodríguez González, 2002: 128).

La visita pastoral, ya practicada en la Edad Media, se erigió en obligatoria tras el Concilio de Trento. La obligatoriedad garantizaba, al menos una vez durante el mandato de cada prelado, el contacto del pueblo cristiano con su pastor, y era claro signo de su autoridad en la diócesis. Su revestimiento pastoral y paternalista no debería hacer olvidar el profundo significado de control subyacente. $Y$ es que mediante la visita, se inspeccionaban el estado material y espiritual de las parroquias, la disciplina clerical y las prácticas religiosas de los fieles, por citar tres elementos (Irigoyen y García Hourcade, 2006: 293-294; Cortés Peña y López Muñoz, 1996: 301-311). El arzobispo de Toledo contaba con un visitador para las parroquias de Toledo, y un tribunal de visita para los conventos de filiación y obediencia al ordinario. En algunas vicarías (Ciudad Real, Cazorla, Huéscar, Puente del Arzobispo, Alcaraz, Alcázar de San Juan) recaía sobre el vicario el cargo de visitador de su partido. Para el resto del territorio, además, se nombraban visitadores de partido no adscritos a un tribunal fijo.

El promotor fiscal, por su parte, era nombrado por el prelado para que, en el tribunal contencioso, persiguiera todos los delitos cometidos por los eclesiásticos bajo su jurisdicción. También le era confiada la defensa de los derechos e inmunidades de la diócesis (André, 1848: II, 216). En el arzobispado de Toledo, además del promotor fiscal general, residente en Toledo, había algunas fiscalías territoriales que coincidían con las vicarías: Alcalá de Henares, Talavera de la Reina, Alcázar de San Juan,

\footnotetext{
7 Además de la propia de la ciudad de Toledo que tenía como competencia supervisar 19 parroquias latinas y 6 de rito mozárabe (Fernández Collado, 2002: 124).
} 
REDES- Revista hispana para el análisis de redes sociales

Vol.21,\#6, Diciembre 2011

http://revista-redes.rediris.es

Alcaraz, Ciudad Real, Cazorla y Huéscar contaban con una (Guía 1795: 41-47). El promotor fiscal, por último, debía estar ordenado in sacris (Quiroga, 1583: 72).

\section{El entorno del arzobispo: la familia y la curia}

Entre los actores que más de cerca rodeaban al arzobispo, no se deben confundir dos grupos nítida y funcionalmente diferenciados: a) la familia episcopal propiamente dicha, compuesta de sus servidores personales y confidentes más íntimos, y b) la curia episcopal, formada por sus colaboradores en el gobierno del arzobispado. Ambas categorías no son necesariamente excluyentes. Se puede pertenecer a ambas al mismo tiempo, y a veces aparecen confundidos en la tratadística y la documentación, aunque, como se verá, las diferencias son muy notables.

\section{a) El servicio personal del arzobispo: la familia}

De entre las distintas acepciones que el Diccionario de Autoridades recoge para la voz "familia", es la tercera la que hace referencia al uso actual de ella, restringida al círculo de parientes más cercanos. Las dos primeras remiten, por su parte, al mando del pater familias en su casa y al conjunto de los subordinados de éste, en que entraría la familia episcopal como paralelo eclesiástico de la casa aristocrática. Así, el vocablo "familiar" no significa, en ninguna de sus entradas, ningún tipo de parentesco; y sí, para lo que aquí interesa, "el Criado o sirviente de una casa; y en este sentido y otros se usa esta voz como sustantivo, y es más común en las casas de los Prelados eclesiásticos" ${ }^{\prime \prime}$.

En la difusa categoría de los "familiares" del arzobispo se engloban todos los oficiales de la secretaría de la Cámara del prelado, que ayudaban a éste en la redacción de escritos, de cartas, y demás trámites burocráticos y despacho de negocios a realizar en su palacio; pajes y mayordomos, muchos de ellos procedentes de distinguidas parentelas, a quienes estaba encargado de dar una formación, y que le acompañaban la mayor parte del tiempo; los domésticos, es decir, porteros, cocineros, reposteros, guardarropas, y otros encargados de servirle en sus tareas cotidianas y domésticas más básicas. Otros criados, tales el ayuda de Cámara o el ayuda de Oratorio, cumplían, como su nombre indica, funciones asistenciales muy concretas, mientras que los libreas, vestidos de uniforme, servían de lacayos, tronquistas o mozos de mula, por citar algunas de sus funciones (Rodríguez LópezBrea, 2002: 74).

${ }^{8}$ Diccionario de Autoridades, D-F, Madrid, 1732, pp. 717-719. Versión digital en http://buscon.rae.es/ [consultado 2-12-2010] 
Entre este elenco de servidores, de funciones heterogéneas, había diferencias importantes. Por una parte, cabe hablar de la distinción entre los que eran clérigos y los que no lo eran: en el caso particular de la familia de los arzobispos de Toledo, eran más los seglares que los eclesiásticos, lo cual no debe extrañar dado el alto número de subordinados que tenían. Por la otra, se puede considerar una jerarquía "intrafamiliar", que dividía en dos a los miembros del conjunto, y que también se podía encontrar en Francia (Meyer, 2008: 58 y ss.). Los de "escalera arriba" eran los sirvientes mayores que atendían directamente al prelado en los aposentos altos del palacio: el secretario de Cámara y sus oficiales, los mayordomos de los palacios de Toledo y Madrid, el tesorero, el caballerizo, el penitenciario, y los maestros de ceremonias y de pajes, siendo el primero de ellos el más importante, pues ante él pasaban todas las órdenes y demás actos de gobierno tocantes a la dignidad arzobispal (Rodríguez López-Brea, 2002: 75). Los componentes de esta categoría eran generalmente eclesiásticos, y podían esperar alguna movilidad en el seno del estamento: algunos eran racioneros de la catedral de Toledo, otros gozaban de alguna renta eclesiástica provista por el arzobispo, aunque pocos pasaban este umbral y llegaban a canónigos o a dignidades catedralicias (Morgado, 2006). Los de "escalera abajo" eran, por su parte, los libreas de condición más baja, y sus funciones estaban constreñidas al ámbito de la privacidad. La movilidad ascendente se revelaba, para éstos, bastante más limitada, al ser la mayoría laicos, y cumplir con la tarea colectiva de dar lustre a su señor (Rodríguez López-Brea, 2002: 74-75).

Las Guías Eclesiásticas consultadas no ofrecen la lista completa de todos estos actores. Sin embargo, a la luz de otra documentación pueden realizarse algunas consideraciones sobre su composición. Francisco Antonio Lorenzana pasó al arzobispado de Méjico con veintisiete personas, de las cuales ocho ya formaban parte de su familia siendo obispo de Plasencia. Llevaba con él a un secretario de Cámara con dos ayudantes; a un mayordomo,; un maestro de pajes, un tesorero personal, acompañado de un oficial; ocho pajes, de los cuales 4 continuaban a su servicio en la fecha citada; un caballerizo, un ayuda de cámara, un cocinero con su ayudante, y dos criados menores. A éstos se unían un abogado de cámara, y los integrantes de la curia: el provisor con su propio paje, el fiscal general y el fiscal de testamentos y obras pías ${ }^{9}$. Del total de estas personas, 6 continuaban a su servicio en 1792: cuatro de ellos pajes, el tesorero y el mayordomo, habiendo pasado sólo uno de ellos a ejercer funciones en la curia episcopal (Guía 1792: 46-47).

${ }^{9}$ Archivo General de Indias (AGI), Contratación, legajo 5509, n. 3, r. 24. Información de pasaje a Indias de Antonio Lorenzana Butrón, arzobispo electo de Méjico. Año 1766. 
REDES- Revista hispana para el análisis de redes sociales

Vol.21,\#6, Diciembre 2011

http://revista-redes.rediris.es

El marco relacional en el que se desenvolvían los actores de la familia episcopal era el de una rigurosa subordinación al arzobispo. No había ataduras institucionales que limitaran la voluntad del prelado en el reclutamiento de sus servidores: se puede definir la familia, de hecho, como un "conjunto de personas colocadas bajo la jurisdicción personal del prelado". Así, los familiares se constituyen en su "burbuja protectora", un "batallón de fieles" que le prevenía de posibles influencias o ataques de las élites locales a su acción o a su persona (Dedieu, 2008). No obstante, esta fidelidad incondicional y la subordinación de todos los aspectos de su vida a la de su patrono llevaba implícita su protección y manutención. Era obligación moral del prelado dotar a sus subordinados, a los asistentes de su cámara personal y habitantes de su palacio, de medios para su subsistencia, alojamiento, educación y formación. En algunos casos, sus protegidos podían tener acceso a su capital relacional y simbólico, del que podían obtener dignidades y beneficios eclesiásticos, así como relaciones personales privilegiadas (Irigoyen, 2008: 584).

La cotidianeidad en el trato con el arzobispo creaba, en efecto, vínculos afectivos y obligaciones que se sustantivaban en la obtención de cargos y beneficios, no sólo para el servidor, sino también para los parientes más cercanos y los paisanos de éste, que accedían a la red del mitrado. El secretario de Luis Borbón, Sebastián Gorbea Arechaederra, por ejemplo, ascendió en la jerarquía beneficial de la Iglesia gracias a la mediación de su patrono y jefe. Gorbea había llegado desde el valle de Ayala a Toledo para cursar estudios e iniciarse en la carrera eclesiástica, valiéndose del apoyo de una red de paisanaje asentada ya en la ciudad (Cfr. Angulo, 1994: 40; Aranburuzabala, 2010). Doctorado en Teología por la Universidad de Toledo, fue provista en él una ración de la catedral en $1793^{10}$. Dos años más tarde le fue confiada la formación de Luis Borbón; influyó profundamente en su ideario, iniciándole en el estudio de Santo Tomás y en la defensa de las regalías de la Corona (Rodríguez López-Brea, 2002: 39). Pronto obtuvo una plaza de capellán en la capellanía de Reyes Nuevos de Toledo ${ }^{11}$, y cierta notoriedad en el seno de la sociedad eclesiástica como en la sociedad civil: siendo secretario de Luis Borbón en el arzobispado de Sevilla ${ }^{12}$, Manuel Jiménez Guazo, oficial de la secretaría de Gracia y Justicia, acudía a él para que un ahijado suyo fuera aceptado en la casa del arzobispo como mozo de recados (Rodríguez López-Brea, 2002: 59). El nuncio apostólico en

\footnotetext{
10 El dato sobre el grado académico en Rodríguez López-Brea (2002: 39). El expediente de limpieza de sangre para tomar posesión de su ración en la catedral en ACT (Archivo de la Catedral de Toledo), Limpieza de sangre, exp. 1624

${ }^{11}$ Archivo Histórico Nacional (AHN), Consejos, legajo 15462, exp. 93. Provisión de una plaza de capellán de Reyes Nuevos de Toledo por derecho de resulta. 26-03-1797.
}

12 Luis Borbón fue arzobispo de Sevilla entre 1799 y 1814. 
REDES- Revista hispana para el análisis de redes sociales

Vol.21,\#6, Diciembre 2011

http://revista-redes.rediris.es

Madrid, Felipe Casoni, se hacía eco de sus capacidades y las manifestaba en su correspondencia con la Santa Sede (Ibídem: 91). A partir de 1802, colaboró estrechamente con Manuel Godoy, con quien mantuvo abundante correspondencia, en la elaboración de un plan para la instauración de vicariatos españoles para las órdenes regulares (Ibídem: 109). En paralelo, obtuvo el arcedianato de Écija de la catedral de Sevilla ${ }^{13}$, primero, y el arcedianato de Calatrava de la catedral de Toledo, después ${ }^{14}$.

Se pueden ver en el caso de Sebastián Gorbea los factores que actuaban en la promoción de un integrante de la familia episcopal en el estamento: se observa la importancia de la valía personal del promovido, pues no todos los familiares tenían el mismo éxito, y algunos no se hacían con prebendas ni fama, mientras que otros, como Gorbea, accedían a un capital económico, simbólico y relacional considerable. También, por supuesto, la protección del prelado hacia su servidor jugaba un rol crucial en su ascenso: situado en una posición jerárquica superior, filtraba hacia otras instancias de poder la información sobre sus subordinados de mayor valía personal. No hay que olvidar que el arzobispo, en este caso Luis Borbón, también estaba obligado a rodearse de elementos destacados y eficaces de la sociedad eclesiástica, que dotaran al aparato administrativo del arzobispado y a su equipo de servicio personal de efectividad (aspecto interno) pero que al mismo tiempo redundaran en su beneficio personal, apareciendo como buen gestor de su casa y de su arzobispado (aspecto externo). Por lo tanto, se trataba de una relación de reciprocidad, no orientada en una sola dirección (protección del arzobispo a su familia), y en la que la vertiente funcional se complementaba con un importante componente afectivo (Meyer, 2008: 163).

Así, en mayo de 1802, el arzobispo Luis Borbón escribía al cardenal Antonino Sentmanat, patriarca de las Indias Occidentales, pidiendo que usara de sus competencias para proponer al monarca la candidatura de Sebastián Gorbea a una plaza supernumeraria de sumiller de cortina y oratorio. La primera misiva condensa varios de los elementos que se han descrito. En ella, el arzobispo decía al Patriarca de las Indias y "hermano de toda estimación":

"tengo en mi compañía al Doctor don Sebastián de Gorvea, catedrático de Teología, que fue en esta Universidad, capellán de Señores Reyes Nuevos en esta Ciudad, después Canónigo y arcediano de Écija en mi Santa Iglesia de

\footnotetext{
${ }^{13}$ AHN, Estado, Carlos III, exp. 1134. Expediente de pruebas de Sebastián Gorbea para la orden de Carlos III.

${ }^{14}$ AGP (Archivo General de Palacio), Personal, Caja 475, exp. 10.
} 
REDES- Revista hispana para el análisis de redes sociales

Vol.21,\#6, Diciembre 2011

http://revista-redes.rediris.es

Sevilla, por gracia de los Reyes nuevos señores, y al presente arcediano de Calatrava en esta mi Primada Iglesia: por sus méritos contraídos en beneficio público, por sus notorias circunstancias y distinguida nobleza, y por hallarse condecorado con la Cruz de la Real Distinguida Orden de Carlos III, me tomo la confianza de rogar a Vuestra Eminencia tenga la bondad de proponerle a Sus majestades en la vacante del Marqués del Puerto, para que si fuere de su soberano agrado continuarle las honras, con que le han favorecido, se dignen por un efecto de su suma incomparable beneficencia dispensarle la apreciabilísima honra de nombrarle por su sumiller a fin de que esta nueva condecoración le proporcione la dicha, que anhela este leal, y agradecidísimo vasallo, de ser y llamarse criado de Sus majestades y Real Familia, y prometiéndome de Vuestra eminencia este honor le aseguro mi verdaderos deseos de complacerle, y pido a Dios prospere su vida muchos años"15

Luis Borbón presentaba a su familiar con todos los servicios prestados, y ponía a la disposición de éste su red de relaciones, en orden a que pudiera acceder a recursos en ella embebidos (Cfr. Lin, 2003; Imízcoz, 2007). Sebastián Gorbea se había ido beneficiando de este cauce hacia la gracia regia, por el cual había podido ascender a beneficios y dignidades eclesiásticas del Real Patronato, a honores y distinciones civiles y a la publicación de su valía personal. Algunos días después de la carta citada, se recibió en Toledo la respuesta del Patriarca de las Indias, en la que expresaba una resolución favorable para las pretensiones del secretario del arzobispo $^{16}$. La misiva de agradecimiento es del propio Gorbea, quien se insertaba así en un círculo relacional más amplio a través de su superior, el arzobispo ${ }^{17}$. Tras hacerse efectiva la gracia regia, ambos, arzobispo y secretario, escribieron por separado al Patriarca de las Indias mostrando de nuevo su gratitud por la mediación ante el monarca ${ }^{18}$. El día 25 de mayo de 1802 Gorbea juraba sobre los evangelios ejercer su nuevo cargo fielmente, "guardar y defender constantemente" las regalías

\footnotetext{
${ }^{15}$ AGP, Personal, Caja 475, exp. 10. Carta de Luis Borbón Vallabriga, arzobispo de Toledo, a Sentmenat, Patriarca de las Indias, pidiendo que interceda ante el rey para que Gorbea sea nombrado sumiller de cortina. Toledo, 29 de marzo de 1802.

${ }^{16}$ AGP, Personal, Caja 475, exp. 10. Carta de Sentmenat, patriarca de las indias, a Luis Borbón, arzobispo de Toledo, informando de que se ha recomendado a Sebastián Gorbea, canónigo arcediano de Calatrava de la catedral de Toledo, para sumiller del rey. Madrid, 5 de abril de 1802.

17 Ibídem. Carta de Sebastián Gorbea, arcediano de Calatrava de la catedral de Toledo, a Sentmenat, Patriarca de las Indias. Toledo, 6 de abril de 1802.

18 Ibídem. Carta de Sebastián Gorbea, arcediano de Calatrava de la catedral de Toledo, a Sentmenat, Patriarca de las Indias. Toledo, 12 de abril de 1802. Carta de Luis Borbón Vallabriga, arzobispo de Toledo, a Sentmenat, patriarca de las Indias, agradeciendo haber intervenido en el nombramiento de Sebastián Gorbea como sumiller de cortina del rey. Toledo, 12 de abril de 1802.
} 
REDES- Revista hispana para el análisis de redes sociales

Vol.21,\#6, Diciembre 2011

http://revista-redes.rediris.es

de la casa y capilla del rey, y obedecer al Patriarca de las Indias como a su nuevo prelado $^{19}$.

Sebastián Gorbea no se ocupó solamente de su promoción personal. Como indicaba arriba, los parientes y paisanos del promovido podían acceder, a través de éste, a los recursos que se contenían en otras redes. Esta es una pauta común de las carreras eclesiásticas en el Antiguo Régimen. La promoción de un sujeto o su inserción en una red episcopal provoca un efecto multiplicador del fenómeno al unirse un campo primario de sociabilidad y obligaciones, como es el de la parentela, con la posición alcanzada (Enríquez, 2006: 281; Imízcoz y Del Ser, 2008). Antes de 1795 se encontraba su hermano Andrés Gorbea al servicio de Gregorio Villagómez Lorenzana, sobrino del arzobispo Francisco Antonio Lorenzana y arcediano de Calatrava de la catedral de Toledo, como familiar suyo ${ }^{20}$. En fecha anterior a 1800 , acogió a su sobrino Andrés Gorbea Gancedo, y lo puso bajo la protección de Luis Borbón cuando éste era arzobispo de Sevilla (Oyanguren, 2005). Muerto su tío y valedor en 1804, fue el prelado quien se encargó de su educación y manutención, enviándole al seminario Patriótico de Vergara, donde permaneció hasta 1815. En esta fecha, volvió a formar parte de la familia de Luis Borbón, quien intentó utilizar su capital relacional para colocarlo en la carrera militar ${ }^{21}$.

A la vista de lo dicho, la familia aparece como un séquito asistencial del prelado. Era un conjunto heterogéneo de servidores personales que abarcaban funciones diversas, desde tareas domésticas hasta burocráticas. Los vínculos de los familiares con los arzobispos se extienden en el tiempo, revelando una importante carga afectiva en las relaciones.

\section{b) La curia eclesiástica del arzobispado de Toledo}

La curia de un prelado tiene como función primordial, como se ha dicho, la colaboración en el gobierno de la diócesis. El episcopus, etimológicamente "el que observa desde arriba", delegaba muchas de sus funciones en personas de confianza para abarcar el territorio que le era asignado. En la vigilancia "desde arriba" del arzobispo, los vicarios eran una pieza fundamental y actuaban como sus ojos supletorios. El vicario era titular de un oficio eclesiástico auxiliar, y poseía, como tal,

\footnotetext{
19 Ibídem.

${ }^{20}$ AHN, Estado, Carlos III, exp. 1134, f. 16v.

${ }^{21}$ AGMS (Archivo General Militar de Segovia), legajo 6-3754. Carta de Luis Borbón, arzobispo de Toledo, al Marqués de Campo Sagrado, para que su protegido Gorbea sea admitido a los exámenes Real Cuerpo de Ingenieros. Toledo, 15 de junio de 1816.
} 
la potestad ordinaria delegada del titular de la silla (Haering; Schmitz, 2001: 820821). Estos actores eran los que se ocupaban de la administración del arzobispado, mientras que el prelado, con responsabilidades pastorales - $y$, en lo temporal, políticas- crecientes durante el siglo XVIII (Rosa, 1999: 185-223), tendió a centrarse en su papel de maestro, pastor e intermediario (Châtellier, 2002: 179-180). Conviene ver, por lo tanto, más detenidamente las atribuciones y carácter del oficio de vicario, ya que es fundamental para comprender el núcleo central de este trabajo.

El cargo de vicario general iba unido generalmente al de provisor, aunque su naturaleza y atribuciones tengan notables diferencias que la historiografía no tiende a diferenciar. La fórmula "provisor y vicario general" para una sola persona estaba extendida a tal punto que se identificaban y confundían ambos cargos. De hecho, en España, en el siglo XVIII por lo menos, ambos cargos los desempeñaba una misma persona, y el Diccionario de Autoridades establece una equivalencia total entre ambos términos ${ }^{22}$. Igualmente ocurre en los títulos que despachaban los prelados para estos oficios, cuyas plantillas preveían el desempeño de ambos por una sola persona (Ortíz de Salcedo, 1764: 24). Estrictamente hablando, sin embargo, el vicario general tenía el ejercicio de la jurisdicción graciosa, reservándose la jurisdicción contenciosa al provisor. De esta forma los prelados concedían a los vicarios generales jurisdicción sobre un elevado número de materias: regir, administrar y gobernar la diócesis, sus iglesias y lugares, tanto en lo espiritual como en lo temporal; visitar y corregir parroquias, capillas, hospicios, y demás lugares piadosos; conceder dimisorias para tonsura, órdenes menores y mayores, y examinar a los ordenandos; predicar y hacer predicar, examinar, aprobar o revocar a predicadores; convocar sínodo diocesano; oír confesiones sacramentales de todo tipo, examinar y aprobar a confesores, o revocar las licencias de confesar, en su caso; imponer censuras o penas eclesiásticas; dispensar votos, juramentos, y ayunos en fiestas de guardar cuando hubiere motivo para ello; bendecir iglesias, oratorios, y otros lugares dedicados al culto, así como las campanas, los ornamentos y los lienzos; sustituir a un vicario, o a varios, en caso de enfermedad o ausencia, y poder delegar en ellos todas facultades mencionadas. Sus poderes finalizaban por revocación o muerte del obispo que libremente lo había nombrado para actuar como su cooperador en el ministerio (André, 1848: IV, 346-348). El ejercicio de esta jurisdicción, unida a la contenciosa del provisor, abarcaba casi todo el ministerio episcopal, y así hay que entender que el nombramiento de una persona para provisor

22 Diccionario de Autoridades, O-R, Madrid, 1737, p. 416. 
REDES- Revista hispana para el análisis de redes sociales

Vol.21,\#6, Diciembre 2011

http://revista-redes.rediris.es

y vicario general por un mitrado se enmarcaba en una consideración de fuerte y asentada confianza en la formación, probidad y valía del actor en que recaía el oficio.

Ahora bien, no se debe confundir, como se ha hecho a veces, la vicaría general con la curia episcopal. Ésta es mucho más amplia, y aquélla forma sólo una parte de ella. Como se ha señalado, el arzobispo de Toledo contaba generalmente con otros colaboradores en su ministerio. Entre los más importantes, dos obispos auxiliares, uno en Toledo y otro en Madrid, encargados de administrar aquello únicamente reservado al orden episcopal: a saber, el sacramento de la confirmación y la ordenación sacerdotal. También han sido mencionados los vicarios foráneos, que ejercían la jurisdicción delegada del prelado en un territorio concreto de la diócesis.

Merece la pena, en este punto, detenerse a considerar cuál era el contenido de las relaciones que unían a los arzobispos con los integrantes de su curia. Como en cualquier tipo de trabajo historiográfico que aplique el análisis relacional, en este también es imprescindible la toma en consideración del contexto en el que se producen o dan esas relaciones. El acercamiento a esta realidad contextual puede ser realizado mediante una genealogía de los conceptos, denominaciones, y términos empleados por los mismos actores, en el sentido planteado por M. Foucault (Foucault: 1978, 7-29). ¿Cuál era el significado que, por ejemplo, daban los contemporáneos al mismo nombramiento y ejercicio del oficio de vicario general? ¿Cuáles eran los términos de las relaciones que mantenían el arzobispo de Toledo y sus subordinados? Son preguntas a las que se puede contestar, quizás, con la explotación intensiva de otros tipos documentales, entre los que cabría destacar la correspondencia epistolar, las oraciones fúnebres de prelados, las memorias o los diarios de los miembros de las familias o las curias episcopales. Si bien no puedo llevar a efecto el ejercicio de definición del contenido de las relaciones intraclericales en estas páginas, es posible adelantar algunas consideraciones sobre el tema que aparecerán más elaboradas en futuros trabajos.

Podría pensarse que la relación movilizada por el arzobispo para el reclutamiento de sus colaboradores más directos se concreta en unos vínculos clientelares. La realidad es algo más compleja. El parentesco, primado con respecto a relaciones de otra naturaleza en los análisis de red social aplicados a la investigación histórica no ofrece por sí mismo mayores elementos interpretativos, ni responde a las preguntas planteadas en torno a los criterios de reclutamiento en las curias arzobispales. En el mejor caso, el parentesco se encuentra con las redes de colegiales mayores, las recomendaciones o los informes de otros prelados, el paisanaje tiene su lugar en 
REDES- Revista hispana para el análisis de redes sociales

Vol.21,\#6, Diciembre 2011

http://revista-redes.rediris.es

algunos casos, y en la mayoría de éstos la coincidencia de varios de estos factores es evidente. Lo esencial era que el prelado tuviera una seguridad y confianza en sus curiales, por lo que se para su reclutamiento se movilizaban vínculos de todo tipo. Como apunta L. Enríquez, relaciones de diverso tipo ensamblaban entre sí a obispos de varias generaciones: el parentesco, el patronazgo, los colegios, las universidades, las curias episcopales o los cabildos catedralicios hacen aparecer al episcopado "como un cuerpo que se reproduce a través del establecimiento de los vínculos señalados" (Enríquez 2006: 142).

Como ocurría con los familiares, el prelado elegía a los miembros de su curia con absoluta libertad. Las personas seleccionadas para ser sus colaboradores en el gobierno del arzobispado eran nombradas siguiendo criterios de confianza, afinidad, y valía personal. No obstante, existía en el arzobispado de Toledo cierto tipo de escalafón, por el cual se comenzaba desde vicarías foráneas u otros cargos curiales y se ascendía hacia la vicaría general, como se infiere de las relaciones de méritos de los miembros de la curia, quienes anotaban con precisión todos los ascensos habidos en su carrera ${ }^{23}$. En sus recomendaciones y peticiones a la administración del patronato regio para conseguir del rey prebendas para sus miembros, el arzobispo también hacía ver esta realidad; como hizo Luis Borbón, en 1802, al proponer personas para obispo auxiliar suyo, afirmando que Isidro Charro había "seguido con mucho acierto la carrera de vicarías en este arzobispado"24. Del mismo modo, la carta enviada por el vicario de la plaza de Orán, Pedro Antonio Trevilla, al secretario de cámara Manuel Martínez Nubla, muestra las expectativas creadas en el seno de la curia de ascender en la carrera y conseguir, por este medio, prebendas catedralicias de cierta importancia. Conociendo que Francisco Antonio Lorenzana tenía pensado trasladarle a la visita del partido eclesiástico de Canales, expresaba su preocupación por el riesgo que correría su carrera si el traslado se consumara. Todos los vicarios de la plaza de Orán, decía, habían sido promovidos a vicarías, excepto "Prieto, que por los méritos salió a visitas, y perdió la carrera". Entre los vicarios se tenía "a menos salir para visitas", y eran consideradas, siguiendo al autor de la carta, una

\footnotetext{
${ }^{23}$ Por ejemplo, Relación de méritos en la Cámara de Castilla de José Benito Bárcena, juez del Tribunal de la Gobernación del arzobispado de Toledo. Madrid, 1 de junio de 1796. AHN, Consejos, legajo 15470, exp. 9

${ }^{24}$ AHN, Consejos, legajo 15482, exp. 2. Lista de propuestos por Luis Borbón Vallabriga, arzobispo de Toledo, para obispo auxiliar suyo. Se podrían multiplicar los ejemplos, lo cual me parece innecesario. No obstante, quede como botón de muestra la presentación hecha por el mismo arzobispo de Pedro Javier Rivero Encina, para que su nombramiento como vicario general se aceptara por la Cámara de Castilla, y se aprobara por el rey: "experiencia práctica de la idoneidad de este sujeto desde 1790, que empezó a ejercer judicaturas en este Arzobispado en los destinos de Fiscal, y teniente vicario de Alcázar de San Juan, teniente contador mayor de rentas decimales, y teniente vicario general de Toledo, cuyos conocimientos prácticos ha aumentado después en su destino de Doctoral de Zamora, y en las oposiciones que ha hecho en las iglesias de Cuenca y Zaragoza". AHN, Consejos, legajo 15494, exp. 1, 7 de julio de 1805. Nombramiento de Pedro Javier Rivero y Encina para vicario general de Toledo.
} 
degradación causada por un incorrecto desempeño del cargo. Prefería quedarse sin destino a ser destinado a una visita, y optar a alguna canonjía o dignidad con el recorrido administrativo hecho hasta entonces. $Y$ es que no sólo sentía sobre sí el peso de una posible regresión en su carrera, sino el incumplimiento de las expectativas de sus parientes y valedores o, como él lo exponía, "la censura de los que me juzguen para otras cosas"25.

Emergen en la carta algunos puntos que interesa comentar más detenidamente. Los curiales tienen plena conciencia de estar inmersos en una red administrativa que da opciones de promoción intraclerical. Hay comunicación entre ellos, conocen por experiencia cuáles son las vías que conducen a puestos más altos y al acceso de prebendas eclesiásticas, pero también saben de los caminos que llevan a perder las posibilidades de ascenso. Pedro Trevilla expone claramente las expectativas creadas en torno a su persona como consecuencia de su actividad como vicario de Orán, pero también es consciente de que su futuro queda, en gran medida, en manos del arzobispo, quien debe decidir si continúa en la carrera de las vicarías o pasa a cumplir otro tipo de tareas en la curia. ¿Qué esperaba de su desempeño en la curia del arzobispo de Toledo? ¿Por qué tantas expectativas? Había mucho en juego en la decisión del arzobispo, como se verá en el apartado que sigue.

\section{c) Administración eclesiástica, redes de confianza y cooptación en el episcopado español}

Los dos ámbitos en los que se dividían los servidores del prelado, el del servicio personal y el del gobierno diocesano, aparecen mejor definidos en sus atribuciones si se atiende a la trayectoria posterior de sus actores respectivos. La creciente importancia de la experiencia administrativa previa en el reclutamiento de los altos cuadros clericales (Hermann, 1986: 307), y en particular del episcopado, se deja ver con claridad si se observan, en la diacronía, los vínculos que unen a sus actores durante sus vidas y el devenir de sus carreras. El hecho ya ha sido puesto de manifiesto para España, en forma de propuesta de investigación, por la historiografía reciente (Dedieu, 2005). Lo que falta es un análisis sistemático de este fenómeno particular de cooptación de la jerarquía eclesiástica que en otros países, como Francia, arrojó un resultado extraordinario en cuanto a la comprensión de los mecanismos internos de la clerecía en la configuración de su episcopado (Péronnet, 1977).

\footnotetext{
25 Pedro Trevilla a Manuel Martínez Nubla. Rosalcázar, 8 de marzo de 1792. Citado en Sánchez Doncel
} (1991: 826). 
Como se ha sugerido anteriormente, el acceso a piezas eclesiásticas mayores y a prelacías era mucho más común entre los miembros de la curia que en los de la familia. La movilidad caracterizaba a los actores de la estructura administrativa del arzobispado, lo que contrasta con la permanencia por largos periodos en sus cargos de los familiares. Pocos eran los que transitaban, además, de un ámbito al otro en el cumplimiento de sus funciones. En cualquier caso, las relaciones en cada campo y las posibilidades que otorgaban, no se pueden ver en toda su plenitud sino a la luz de los datos que se exponen a continuación.

He preparado el gráfico 1 para introducir una primera aproximación visual al fenómeno que voy a tratar. En él, se muestran tres arzobispos de Toledo de la segunda mitad del siglo XVIII y comienzos del XIX, vinculados a los miembros de la administración diocesana elegida por ellos. Las relaciones son de estricta subordinación y, como tales, se podrían asimilar a vínculos de patronazgo y clientela - aunque, como queda dicho, el contenido de los vínculos es más complejo. Los arzobispos, como se puede observar, están representados por vértices de mayor tamaño, lo cual indica un número más elevado de relaciones documentadas con sus subordinados, que el mismo paquete informático Pajek calcula automáticamente. Con respecto a los empleados en su servicio administrativo, los vértices van marcados con colores que se refieren a la trayectoria posterior de los actores, que es donde reside el núcleo argumental de este trabajo. Así, los marcados en rojo llegaron a ser obispos o arzobispos de sillas españolas - de ahí que dos de los arzobispos de Toledo también vayan marcados con este color. Respecto de los vértices en color verde, indican que el actor consiguió ser nombrado obispo, o arzobispo de una o varias sillas americanas. Los vértices en cyan, por su parte, señalan a obispos o arzobispos de sillas españolas y americanas - de ahí que Francisco Antonio Lorenzana aparezca como tal. Por otra parte, hubo una fracción de los empleados de estas curias, que van marcados en color amarillo, que no llegaron a ser obispos, pero que consta figuraron en las Consultas de la Cámara de Castilla o en las listas que la Secretaría del Real Patronato elaboraba con la nómina de candidatos para mitras que quedaban vacantes - a quienes designaré como episcopables. Finalmente, los vértices azules, los más numerosos por razones que después expondré, fueron los empleados de la curia diocesana no mitrados - cuyos destinos variaron en función de las circunstancias, pero que tuvieron una notable presencia en los tribunales de la Inquisición, o se limitaron a percibir alguna renta eclesiástica en un cabildo catedralicio ${ }^{26}$.

\footnotetext{
${ }^{26}$ Por razones de espacio, expondré los pormenores de estas trayectorias posteriores en otro trabajo.
} 


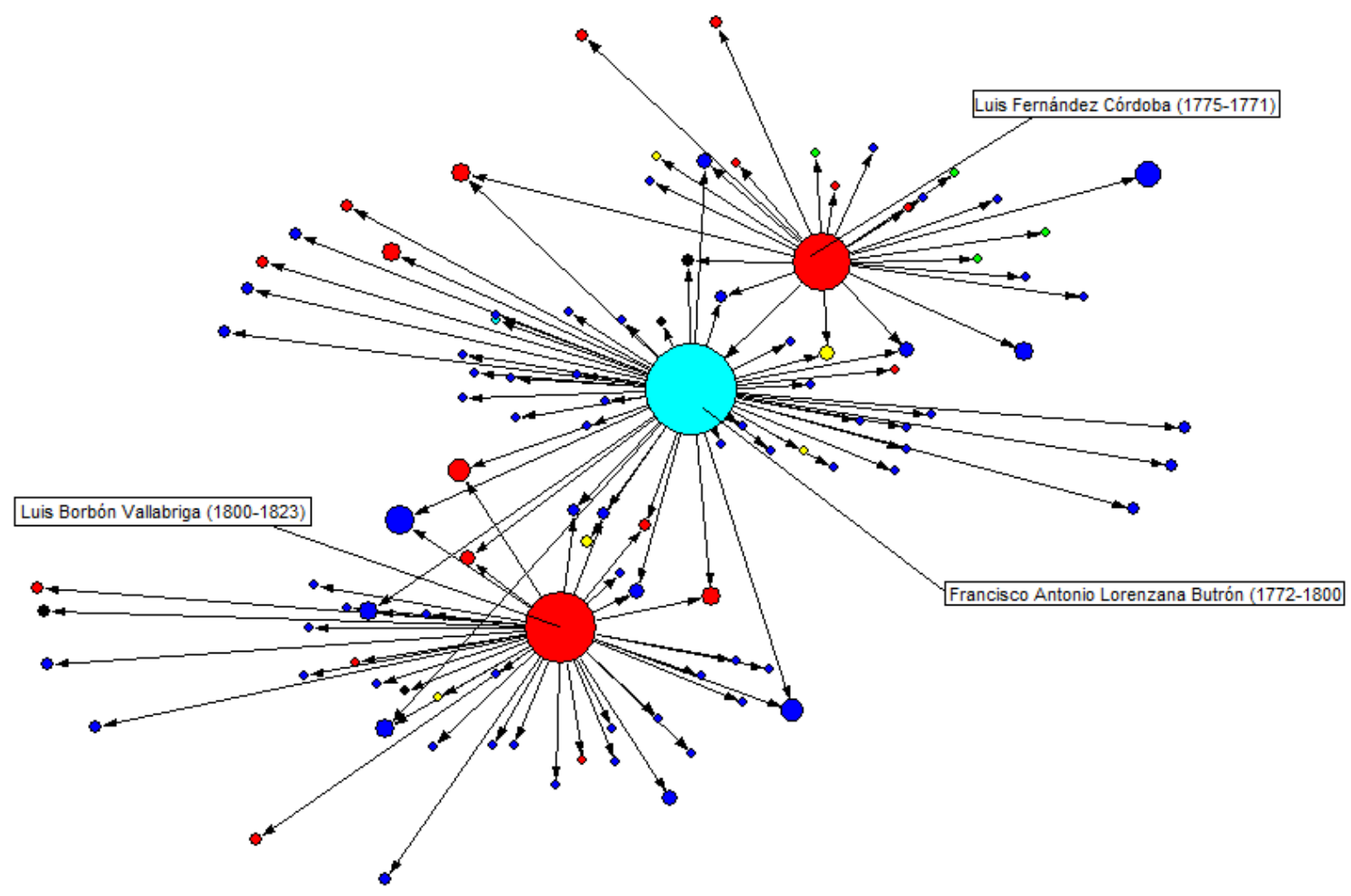

Gráfico 1: Curias de los arzobispos de Toledo.

Partiendo de los datos recogidos y procesados, y aclarados los extremos más básicos de las relaciones entre los arzobispos y los miembros de sus curias, expondré de forma sintética sus trayectorias en el seno de la administración eclesiástica, con el objetivo de ver cómo, efectivamente, la jerarquía clerical actuaba como reproductora de sus mismos sucesores. Para esto, seguiré un esquema cronológico, comenzando por los mitrados salidos de las curias de los tres arzobispos que se han considerado. Así, Francisco Antonio Lorenzana ocupó el cargo de vicario general del arzobispado de Toledo por nombramiento de Luis Fernández Córdoba en 1755. Desarrolló satisfactoriamente las tareas que le eran asignadas por el prelado, dotándole de una experiencia administrativa de primera magnitud (Sierra, 1975: 79-100). Anteriormente había destacado en el ejercicio de la canonjía doctoral de la catedral de Sigüenza, que poseía desde 1751, y por la cual corría a su cargo el asesoramiento jurídico del cabildo catedralicio (Sánchez Doncel, 1961). En 1765 fue nombrado por el rey para el obispado de Plasencia, y sin tomar posesión de éste, pasó en 1766 al 
REDES- Revista hispana para el análisis de redes sociales

Vol.21,\#6, Diciembre 2011

http://revista-redes.rediris.es

arzobispado de Méjico. Tras la muerte del arzobispo de Toledo, su valedor, ocupó esta mitra en $1772^{27}$. Como se puede observar el el gráfico 1 , no fue el único de los curiales de Fernández de Córdoba en ascender a mitras. Agustín González Pisador, obispo auxiliar para Madrid desde 1754, ascendió al obispado de Oviedo en $1760^{28}$; y su sucesor en el obispado auxiliar, Juan Manuel Argüelles, al de Palencia ${ }^{29}$, en 1769. Manuel Torres Fernández, visitador de Madrid y vicario general del arzobispado, pasó al gobierno del obispado de Ceuta en $1771^{30}$. También vicario general, Juan Antonio de los Tueros Llaguno accedió al arzobispado de Burgos en $1791^{31}$. Juan Díaz Guerra, juez de la gobernación, recaló en el de Mallorca en 1772, y en el de Sigüenza en 1777, tras pasar por el tribunal de la Rota romana ${ }^{32}$. Gabino Valladares, vicario eclesiástico de Madrid, fue elevado a la mitra de Barcelona en $1775^{33}$. En Indias, ocuparon sillas, además del mismo Lorenzana, Diego Díez Madroñero, quien ocupando la vicaría general de Alcalá de Henares fue nombrado para el obispado de Caracas en $1756^{34}$; desde la de Toledo, Juan Francisco Calvo fue promovido para el gobierno del de Santa Marta en $1771^{35}$. El visitador general y juez eclesiástico del arzobispado, Antonio Macarulla, tuvo como destino los obispados de Comayagua y de Durango, en 1767 y 1772 , respectivamente ${ }^{36}$. El cierre de un círculo tuvo lugar con la elección por el rey de Alfonso Núñez Peralta, visitador general, para el arzobispado de Méjico, en el que venía a sustituir al mismo Francisco Antonio Lorenzana, salido de la misma curia a igual destino ${ }^{37}$.

En el gozne de los pontificados de Luis Fernández de Córdoba y Francisco Antonio Lorenzana hay que situar a Cayetano Peña Granda, ya que trabajó para ambos

\footnotetext{
27 Archivo General de Simancas (AGS), Gracia y Justicia, legajo 306. Consulta de la Cámara de Castilla para la provisión del arzobispado de Toledo, vacante por muerte de de Luis Córdoba. 17 de abril de 1770 .

${ }^{28}$ Vid. Tuñón Escalada (2000).

${ }^{29}$ AGS, Gracia y Justicia, legajo 310. Consulta de la Cámara de Castilla para la provisión del obispado de Palencia, vacante por muerte de José Loaces. 14 de noviembre de 1769.

${ }^{30}$ AGS, Gracia y Justicia, legajo 312. Consulta de la Cámara de Castilla para la provisión del obispado de Ceuta, vacante por muerte de José Rivero Quijano. 20 de febrero de 1771.

${ }^{31}$ AHN, Consejos, legajo. 15439, expediente 1. Consulta de la Cámara de Castilla para la provisión del arzobispado de Burgos, vacante por muerte de José Javier Rodríguez Arellano. 3 de agosto de 1791.

32 AGS, Gracia y Justicia, legajo 509. Lista de candidatos al obispado de Sigüenza, vacante por promoción de Francisco Delgado al arzobispado de Sevilla, formada por la Cámara de Castilla valiéndose de informes de prelados y de consultas precedentes.

33 AHN, Consejos, legajo 19523. Nombramiento Gabino Rafael Valladares Mesía para el obispado de Barcelona. Madrid, junio de 1775.

${ }^{34}$ Fichoz: 029937. Agradezco su consulta al profesor Jean Pierre Dedieu y a todos los investigadores que trabajan o han trabajado en esta base de datos.

35 Fichoz: 030138.

${ }^{36}$ Fichoz: 017423.

37 Fichoz: 023502.
} 
REDES- Revista hispana para el análisis de redes sociales

Vol.21,\#6, Diciembre 2011

http://revista-redes.rediris.es

prelados en su destino de vicario eclesiástico de Madrid. En una primera etapa, estuvo a las órdenes de Manuel Torres Fernández, vicario de Madrid, como su teniente. Nombrado éste para obispo de Ceuta, se lo llevó consigo de provisor y vicario general de aquel obispado, volviendo a Madrid tras su muerte para trabajar en su vicaría. Tras algunos años en este destino, pasó a regir el obispado de Huesca en $1790^{38}$. Francisco Aguiriano Gómez, estrecho colaborador de Francisco Lorenzana desde sus días en el arzobispado de Méjico, donde ocupó los cargos de provisor y vicario general, actuó como su obispo auxiliar desde 1776, alcanzando la mitra de Calahorra en $1790^{39}$. Lorenzo Igual de Soria, sucesivamente teniente vicario, vicario general y juez eclesiástico de Alcalá de Henares, y vicario eclesiástico de Madrid, fue primeramente obispo de Pamplona (1795) y, después, de Plasencia $(1803)^{40}$. El riojano José Sáenz de Santa María, hombre de confianza de Lorenzana desde el año 1773 (en que fue nombrado provisor y vicario general de Toledo), hasta 1797 (en que terminó sus días como vicario de Madrid) gobernó el obispado de Segovia hasta $1813^{41}$. Por último, Francisco Lizana Beaumont, fiscal del arzobispado, y más tarde obispo auxiliar, rigió los destinos del de Teruel desde 1800, y, en 1803, sustituyó al fallecido arzobispo de Méjico Alfonso Núñez Peralta; se convertía en el tercer mitrado consecutivo de aquella sede salido de la curia episcopal de Toledo ${ }^{42}$.

La sucesión de vicarios generales en el arzobispado se interrumpió con el nombramiento de Luis Borbón Vallabriga, a quien, como miembro de la familia real y protegido de Manuel Godoy, no le hizo falta ningún tipo de experiencia previa para ascender al episcopado. Sin embargo, varios actores, después obispos, conectan ambos pontificados: Buenaventura Moyano, gobernador del arzobispado con Lorenzana, fue elegido por éste para obispo auxiliar, cargo que ejerció efimeramente con Borbón, y ascendió al obispado de Palencia en $1801^{43}$. Pedro Trevilla, fiscal eclesiástico de Alcázar de San Juan, vicario de Orán y de la ciudad de Toledo con el

\footnotetext{
38 Su relación de méritos extractada en AGS, Gracia y Justicia, legajo 326. Consulta de la Cámara para la provisión del obispado de Tortosa, vacante por renuncia de Pedro Cortés Larraz. 14 de junio de 1786. También, Polo (2001-2003).

39 Saínz Ripa (1997: 225-230). AHN, Consejos, legajo 15435, expediente 1: Consulta de la Cámara de Castilla para la provisión del obispado de Calahorra, vacante por muerte de Pedro Luis Ozta Múzquiz. 21 de octubre de 1789.

40 Goñi Gaztambide (1989: 365).

${ }^{41}$ Sierra Nava (Luis), op. Cit., p. 52. AHN, Consejos, legajo 15454, expediente 1. Real Decreto nombrando a José Sánez de Santa María para el obispado de Segovia. Aranjuez, 1 de mayo de 1796. Fichoz: 016438.

42 AHN, Consejos, 19510, expediente sin numerar. provisión del obispado de Teruel en Francisco Javier Lizana. Año 1800. Ibídem, presentación del obispado de Teruel en Blas Joaquín Álvarez Palma, por promoción de Francisco Lizana a arzobispado de México, 1803.

43 Ceballos (2005: 501). AHN, Consejos, legajo 15475, expediente 6. Consulta de la Cámara de Castilla para un obispo auxiliar de Toledo en la ciudad de Toledo, por promoción de Francisco Javier Lizana a Teruel. 3 de septiembre de 1800.
} 
primero, se encargó de la vicaría general del arzobispado con el segundo, y acabó ocupando la mitra de Córdoba desde 1805; Atanasio Puyal, finalmente, fue obispo auxiliar de ambos prelados, y obispo residencial de Calahorra en 1814, diócesis en la que tomó el relevo de Francisco Aguiriano, antiguo compañero de curia ${ }^{44}$. Ildefonso Cañedo (visitador y vicario general) y José Jiménez (visitador y fiscal de obras pías) sirvieron en la curia de Luis Borbón, ascendiendo a las sillas de Málaga y Burgos $(1814 \text { y } 1825)^{45}$, y Cartagena (1806), respectivamente ${ }^{46}$. Alfonso Aguado Jaraba, obispo auxiliar con Borbón, fue electo del obispado de Calahorra por el gobierno de José I Bonaparte ${ }^{47}$. Por último, más alejado en el tiempo, Joaquín Barbarejo Villar, fiscal eclesiástico de Madrid en los últimos tiempos del pontificado ${ }^{48}$, ascendió a la mitra de León en 1848.

Las cifras son elocuentes: veintidós nuevos mitrados encuentran su origen en las curias de tres arzobispos de Toledo. Cuatro de ellos fueron obispos en América, uno en ambos hemisferios y los demás sólo en España. Además, al menos cinco de sus compañeros figuraron en las listas ministeriales para ocupar sillas episcopales en diferentes épocas. Casi todos ellos fueron vicarios, generales o foráneos, u obispos auxiliares. No se observa ningún caso en que un familiar del prelado, tal como se ha definido, obtuviera una prelacía sin pasar antes por un cargo administrativo. El gráfico 2 muestra a tres familiares que ascendieron al episcopado: todos ellos se iniciaron en tareas propias de la familia del arzobispo, pero pasaron después a ocupar otras funciones en la curia. Son los casos de Gabino Valladares, familiar de Francisco Lorenzana desde sus días en Méjico, y después vicario de Madrid; Francisco Aguiriano Gómez, abogado de cámara del mismo arzobispo al pasar a Nueva España, y obispo auxiliar suyo en España; Atanasio Puyal, también abogado de cámara, y después obispo auxiliar. Por último, está Francisco Acedo Torres, quien realizó el camino inverso, siendo nombrado para el obispado de Pamplona (que rechazó), para acabar como secretario de cámara de Luis Borbón ${ }^{49}$.

\footnotetext{
${ }_{44}$ AHN, Consejos, legajo 15435, expediente 6. Propuesta del arzobispo de Toledo, Francisco Lorenzana Butrón, para obispo auxiliar de Toledo, vacante por promoción de Francisco Mateo Aguiriano al obispado de Calahorra. Febrero de 1790.

45 Mondéjar (1998: 319-322); Fichoz: 016248; Guía (1808: 46).

${ }^{46}$ Guía (1804: 43); Fichoz: 016589.

${ }^{47}$ AHN, Consejos, legajo 15482, expediente 2. Consulta de la Cámara de Castilla para el nombramiento de obispo auxiliar de Toledo, 14 de marzo de 1804; Saínz Ripa (1997: 254).

${ }^{48}$ Guía (1823: 25).

${ }^{49}$ AGS, Gracia y Justicia, libro 373, f. 5v; Guía (1784: 34).
} 


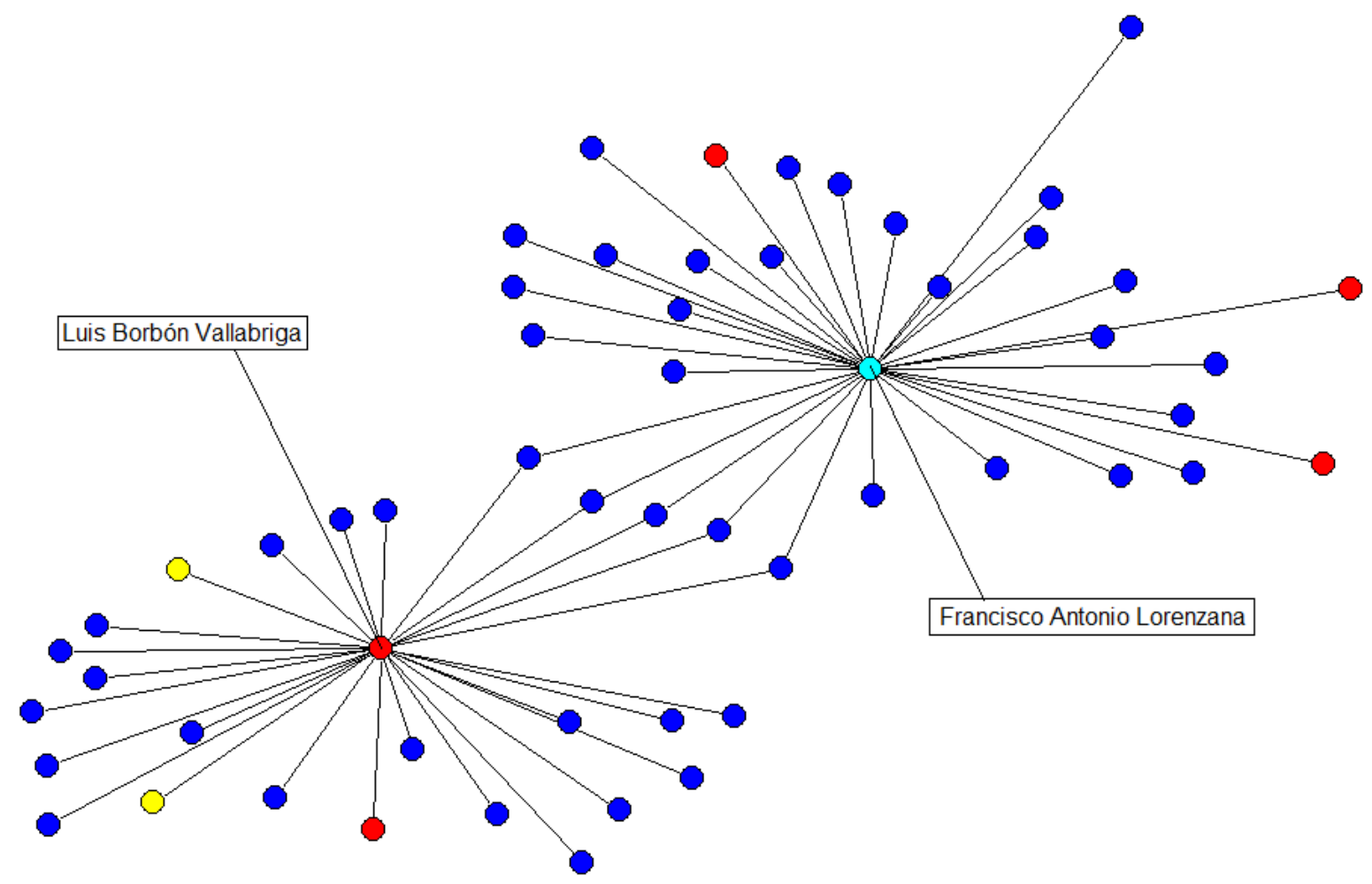

Gráfico 2. Familias de los arzobispos de Toledo 50

Claro está, no todos los vicarios y demás miembros de la curia consiguen pasar al episcopado. Esto no debe restar importancia al fenómeno que se está viendo; entra en una simple lógica de disponibilidad de mitras. Hay más empleados en la curia de los que se puedan ascender al episcopado. Aunque en España, al contrario que en Francia, la mayoría de prelados contaban con un solo vicario general, sus curias eran numerosas. Hay que tener en cuenta, por otra parte, que tanto España como Indias se caracterizaban por un alto porcentaje de clérigos regulares en su episcopado (Barrio, 2004: 156), los cuales quedaban fuera de estas redes al ocupar cargos en su respectiva orden, y no en el ámbito diocesano. Por último, hay un hecho que no se ha tenido muy en cuenta: el ministerio episcopal era una tarea de enorme responsabilidad, que requería disposición y de una conciencia de la misión que no exigían otros cargos. Muchos clérigos preferían vivir de las rentas de una canonjía o dignidad catedralicia tras haber servido en la curia de algún obispo, sin tener que

\footnotetext{
${ }^{50}$ La leyenda del gráfico se corresponde con la del gráfico 1. Vértices rojos: obispos o arzobispos de sillas españolas. Vértices verdes: obispos o arzobispos de sillas americanas. Vértices cyan: obispos o arzobispos de sillas españolas y americanas. Vértices amarillos: actores episcopables. Vértices azules: familiares no mitrados.
} 
REDES- Revista hispana para el análisis de redes sociales

Vol.21,\#6, Diciembre 2011

http://revista-redes.rediris.es

cumplir con el alto cometido del pastor eclesiástico. De ahí el alto número de renuncias a nombramientos que se registran durante el Antiguo Régimen (Ibídem: 173-222).

En conclusión, se ha visto un caso de cooptación al episcopado, por el cual el nombramiento de vicario general u obispo auxiliar del arzobispo de Toledo otorgaba altas posibilidades de ser considerado para alguna prelacía. Las experiencia adquirida en el desempeño de este oficio era un capital inmaterial de peso en la elección de obispos, lo que deja en claro el papel de valedor del prelado a la hora de elegir a sus subordinados, ya que mediante esta vía garantizaba frente a otras instancias la integridad y capacidad de un sujeto para gobernar una mitra en propiedad.

\section{Conclusiones}

Caracterizar este fenómeno como "cooptación" no significa perder de vista otros factores que influían en los nombramientos episcopales. La monarquía controlaba al episcopado a través del patronato regio, por el cual gozaba de la prerrogativa de presentar a sus candidatos para las mitras, tras lo cual eran nombrados por el Papa. Durante el siglo XVIII, el rey y sus ministros alcanzaron altas cotas de fiscalización política del episcopado español: escrutaban sus carreras y relaciones, sus tendencias de pensamiento y formación doctrinal, su producción escrita y sus vínculos con la Santa Sede, con lo que ponía en constante prueba su fidelidad política (Cortés, 2001; Barrio, 2002). Las redes construidas en torno al rey, y las camarillas ministeriales, así como el contexto político, condicionaban la constitución de la jerarquía eclesiástica española. Esto ayuda a entender, por una parte, el acceso de los vicarios eclesiásticos de Madrid al episcopado: la información sobre sus capacidades de gobierno era directa, podían conocer personalmente a los secretarios del rey y a los camaristas de Castilla, y tener rápida noticia de las vacantes ocasionadas en las mitras. No obstante, también explica la súbita interrupción de algunas carreras hacia la mitra. Por ejemplo, la de Juan Varrones Arangoiti, vicario de Madrid por el arzobispo Luis Fernández Córdoba, que siendo consultado para varios obispados entre 1762 y 1767 , desapareció absolutamente tras haberle sido interceptada la correspondencia con el secretario de cámara del prelado. Crítico con el progresivo incremento del control de la corona sobre las estructuras eclesiásticas, Manuel de Roda, secretario del despacho de Gracia y Justicia, consideró pertinente desterrarle en Lezama de Ayala, pueblo de su naturaleza, marcándole con el estigma del 
REDES- Revista hispana para el análisis de redes sociales

Vol.21,\#6, Diciembre 2011

http://revista-redes.rediris.es

jesuitismo y acusándole de conspiración ${ }^{51}$. En adelante, no se volvió a tratar de él como uno de los posibles integrantes del episcopado.

Por lo tanto, los factores mencionados condicionaban, sí, pero no determinaban. El rey parece tener más un derecho de veto a los candidatos preseleccionados en el seno de la sociedad eclesiástica que una verdadera libertad de elección. El ejemplo de Luis Borbón, cuyo ascenso no responde a una criba previa del alto clero, es la excepción más que la regla. En este aspecto, la focalización excesiva de la historiografía en el papel del rey han conducido a la desatención de las dinámicas internas, autónomas - que no autosuficientes-, del alto clero.

Es cierto que la Corona consiguió durante el siglo XVIII intervenir con un importante protagonismo en el gobierno de la Iglesia en sus dominios: el concordato de 1753, la constitución de la Rota española, la expulsión de los jesuitas, la erección de seminarios conciliares, la supervisión de los planes de estudio de los eclesiásticos, entre muchos otros hechos, lo atestiguan. Los intentos de controlar las estructuras eclesiásticas en su favor fueron continuos. Sin embargo, la monarquía no podía introducirse en la administración de la salvación, ni apropiarse de la autoridad espiritual o de la transmisión del mensaje evangélico, exclusivamente reservadas al clero.

Cabría preguntarse, a la luz de lo dicho, cómo la Iglesia continuó funcionando sin cambios institucionales de calado tras la sustitución de las convenciones políticas del Antiguo Régimen. Los casos que se han visto no corresponden más que al arzobispado de Toledo, y aun así, suponen una muestra significativa de una realidad de mayor extensión que podría explicar, en parte, cuestiones importantes sobre la Historia del clero en España desde 1808 en adelante. Porque la exposición de los datos que se han visto conduce indefectiblemente a la cuestión del reclutamiento y la reproducción de las élites clericales en el Antiguo Régimen. Habría que analizar con mayor detenimiento el contenido de las relaciones que subyacen a estos vínculos administrativos, para calibrar el peso del fenómeno en la transmisión de un ideario o una eclesiología concreta que se produciría en el seno de estas redes, y la formación de grupos e ideas divergentes en la jerarquía eclesiástica española, cuestiones de particular relevancia. El análisis de redes puede dar, en el futuro, alguna clave para la comprensión de un proceso de cambio del que aún hay mucho por investigar.

\footnotetext{
${ }^{51}$ Las consultas en las que fue propuesto para mitras, en AGS, Gracia y Justicia, legajos 303, 306, 307, 308. También apareció como candidato al obispado de Tarazona en una lista elaborada en la secretaría del Patronato de Castilla. AGS, Gracia y Justicia, leg. 337. Su correspondencia en AGS, GJ, leg. 777. Sobre su destierro al valle de Ayala, Pinedo (1983: 160).
} 
REDES- Revista hispana para el análisis de redes sociales

Vol.21,\#6, Diciembre 2011

http://revista-redes.rediris.es

\section{Bibliografía}

Angulo Morales, Alberto (1994). Eugenio de Llaguno y Amirola (1724-1799). Una figura emblemática en la difusión y patrocinio de los vascos y la cultura ilustrada. Vitoria: Diputación Foral de Alava.

Aranburuzabala, Yolanda (2010). "Grupos de parentesco en la carrera del honor: los caballeros del valle de Ayala en el siglo XVIII", en Levi, Giovanni (ed.); Pérez, Raimundo (comp.). Familias, jerarquización y movilidad social. Murcia: Universidad de Murcia.

Barrio Gozalo, Maximiliano (2010). El clero en la España moderna. Córdoba: CajasurCSIC.

-(2004). El Real Patronato y los obispos españoles del Antiguo Régimen (15561834). Madrid: Centro de Estudios Políticos y Constitucionales.

-(2002). "El clero bajo sospecha a principios del siglo XVIII. El informe de Macanaz y las respuestas de los obispos". Investigaciones Históricas. Época moderna y contemporánea, no 22, pp. 47-62.

Boudon, Jacques Olivier (1996). L'épiscopat français à l'époque concordataire (18021905). Origines, formation, nomination. Paris: CERF.

Candau Chacón, María Luisa (1993). Los delitos y las penas en el mundo eclesiástico sevillano del siglo XVIII. Sevilla: Diputación.

Castellano, Juan Luis; Dedieu, Jean Pierre; López-Cordón, María Victoria, eds. (2000). La pluma, la mitra y la espada. Estudios de historia institucional en la Edad moderna. Madrid / Burdeos: Temiber / Marcial Pons.

Ceballos-Escalera Gila, Alfonso (2005). "Familia, nacimiento, crianza y semblanza de Monseñor el Doctor Buenaventura Moyano Rodríguez (1755-1802), canónigo de Ávila, Obispo titular de Sebastopol y efímero Obispo de Palencia". Publicaciones de la Institución Tello Téllez de Meneses, n. 76, pp. 499-507.

Châtellier, Louis (2002). "Une enquête à ouvrir: les collaborateurs directs de I'êveque (suffragants et vicaires géneraux) dans I'Europe des XVIe-XVIIe siècles", Chaix (Gérald) (dir.): Le Diocèse. Espaces, représentations, pouvoirs (France, XVeXXe siècles). París: CERF, pp. 179-198. 
REDES- Revista hispana para el análisis de redes sociales

Vol.21,\#6, Diciembre 2011

http://revista-redes.rediris.es

Cortés Peña, Antonio Luis (2001). Religión y política en la Edad Moderna. Granada: Universidad de Granada.

-y López Muñoz, Miguel Luis (1996). "Las visitas "ad limina" y las visitas pastorales como instrumento de control (la diócesis de Granada en la segunda mitad del siglo XVIII), en Sociedad, administración y poder en la España del Antiguo Régimen. Granada: Universidad de Granada/Diputación Provincial de Granada, pp. 287 - 313

Dedieu, Jean Pierre (2005): "Pour une approche relationnelle de l'épiscopat: I'Espagne du XVIIIe siècle", en Sous le sceau des Réformes / Au contact des Lumières, Hommage à Philippe Loupés. Bourdeaux: Presses universitaires de Bourdeaux.

-(2008). "El séquito de los obispos que pasaron a América en el siglo XVIII", en Aguirre Salvador, Rodolfo; Enriquez Agrazar, Lucrecia, (eds.). La Iglesia Hispanoamericana, de la colonia a la república. México: Instituto de Investigaciones sobre la Universidad y la Educación (IISUE); UNAM; , Pontificia Universidad Católica de Chile; Plaza y Valdés Eds., pp.

Enriquez Agrazar, Lucrecia (2006). De colonial a nacional: la carrera eclesiástica del clero secular chileno entre 1650 y 1810. Méjico: Institutio Panamericano de Geografía e Historia.

Fernández Collado, Ángel (2002). Los informes de visita ad limina de los arzobispos de Toledo. Cuenca: Ediciones de la Universidad de Castilla-La Mancha.

Foucault, Michel (1978). Microfísica del poder. Madrid: Ediciones La Piqueta.

Gonzálvez Ruiz, Ramón (2006). "La primacía de Toledo y su ámbito territorial". Memoria Ecclesiae, n. 18, pp. 383-438.

Goñi Gaztambide, José (1989). Historia de los Obispos de Pamplona. Siglo XVIII. Pamplona: EUNSA-Gobierno de Navarra.

Haering, Stephan; Schmitz, Heribert (2001). Diccionario enciclopédico de derecho canónico. Barcelona: Herder. [Freiburg im Breisgau, 2001].

Hermann (Christian) (1988). L'Eglise d'Espagne sous le patronage royal (14761834). Madrid: Casa de Velazquez. 
REDES- Revista hispana para el análisis de redes sociales

Vol.21,\#6, Diciembre 2011

http://revista-redes.rediris.es

Imizcoz Beunza, José María; García del Ser, María Victoria (2008). "El alto clero vasco y navarro en la Monarquía hispánica del siglo XVIII: bases familiares, economía del parentesco y patronazgo", en Aguirre Salvador, Rodolfo; Enriquez Agrazar, Lucrecia, (eds.). La Iglesia Hispanoamericana, de la colonia a la república. México: Instituto de Investigaciones sobre la Universidad y la Educación (IISUE); UNAM; Pontificia Universidad Católica de Chile; Plaza y Valdés Eds., pp. 125-187.

-(2009). "Élites administrativas, redes cortesanas y captación de recursos en la construcción social del Estado moderno". Trocadero. Revista de Historia Moderna y Contemporánea, n. 19, pp. 11-30.

Irigoyen López, Antonio (2008). "Un obispado para la familia: Francisco Verdín Molina, prelado de Guadalajara y Valladolid en la segunda mitad del siglo XVII". Historia Mexicana, LVIII: 2, pp. 557-593.

-(2005). Un obispo, una diócesis, un clero: Luis Belluga, prelado de Cartagena. Murcia: Real Academia Alfonso X El Sabio.

- y García Hourcade, José Jesús (2006). "Las visitas pastorales, una fuente fundamental para la historia de la Iglesia en la Edad Moderna". Anuario de Historia de la Iglesia, n. 15, pp. 293-301.

Lin, Nan (2003). Social capital: a theory of social structure and action. Cambridge: Cambridge University Press.

MacManners, John (1999). Church and society in eighteenth-century France: the Clerical Establishment and its Social Ramifications. New York: Oxford University Press.

Meyer, Frédéric (2008). La Maison de l'évêque. Familles et curies épiscopales entre Alpes et Rhône de la fin du XVIe à la fin du XVIIIe siècle. Paris: Honoré Champion.

Mondéjar Cumpian, Francisco (1998), Obispos de la Iglesia de Málaga. Córdoba: Cajasur.

Morales Moya, Antonio (1984). "Política y administración en la España del siglo XVIII (notas para una sociología histórica de la administración pública)". Revista de administración pública, no 105, pp. 167-204.

Morgado García, Arturo (2006). "La Iglesia como factor de movilidad social: las carreras eclesiásticas en la España del Antiguo Régimen", en Chacón Jiménez, 
REDES- Revista hispana para el análisis de redes sociales

Vol.21,\#6, Diciembre 2011

http://revista-redes. rediris.es

Francisco); Monteiro, Nuno; Poder y movilidad social. Cortesanos, religiosos y oligarquías en la Península Ibérica (siglos XV - XIX). Madrid: CSIC , pp. 63 - 96.

-(2000). Ser clérigo en la España del Antiguo Regimen. Cádiz: Universidad de Cádiz.

Oyanguren (Palmira), "El vasco, Andrés Antonio Gorbea Gancedo. Precursor de las matemáticas modernas en Chile", en www.euzkoetxeachile.cl/libros/06AGorbeayGancedo.pdf 2005 [Consultado 21-7-2009]

Pérez Muñoz, Isabel (1992). Pecar, delinquir y castigar: el tribunal eclesiástico de Coria en los siglos XVI y XVII. Cáceres, Institución Cultural El Brocense.

Péronnet, Michel C . (1977). Les évêques de l'Ancienne France. Lille: Atelier de reproduction des thèses.

Pinedo Iparraguirre, Isidoro (1983). Manuel de Roda. Su pensamiento regalista. Zaragoza: Institución Fernando el Católico.

Plongeron, Bernard (1974). La vie quotidienne du Clergé français au XVIIIe siècle. Hachette, París.

Polo Rubio, Juan José (2001-2003). "Episcopologio de Teruel". Aragonia sacra: revista de investigación, n. 16-17, pp. 141-152

Rodríguez López-Brea, Carlos (2002). Don Luis de Borbón: el cardenal de los liberales (1777-1823). Toledo: Junta de comunidades de Castilla-La Mancha.

Rodríguez González, Alfredo (2002). "La administración de justicia arzobispal: la Audiencia de Alcaraz a principios del siglo XVII", en Actas del II Congreso de Historia de Albacete. Albacete: Instituto de Estudios Albacetenses "Don Juan Manuel", vol. III, Edad Moderna, pp. 127-134.

Rosa, Mario (1999). Settecento religioso: politica della ragione e religione del cuore. Venecia: Marsilio.

Saínz Ripa, Eliseo (1997). Sedes episcopales de la Rioja, siglos XVIII - XIX. Logroño: Obispado de Calahorra y La Calzada-Logroño.

Sánchez Doncel, Gregorio (1991). Presencia española en Orán (1509-1792), Toledo: Seminario conciliar. 
REDES- Revista hispana para el análisis de redes sociales

Vol.21,\#6, Diciembre 2011

http://revista-redes.rediris.es

-(1961). "Francisco Antonio de Lorenzana, canónigo doctoral de Sigüenza". Hispania Sacra, XIV, pp. 323-336.

Sierra Nava, Luis (1975). El cardenal Lorenzana y la Ilustración, Madrid, Fundación Universitaria Española.

Tuñón Escalada, Juan José (2000). Don Agustín González Pisador, obispo de Oviedo (1760-1791): Iglesia y sociedad en Asturias. Oviedo, Real Instituto de Estudios Asturianos.

\section{Fuentes impresas}

André, Michel (1848), Diccionario de derecho canonico traducido del que ha escrito en francés el abate Andrés... arreglado a la jurisprudencia eclesiástica española antigua y moderna. Contiene todo lo que puede dar un conocimiento exacto, completo y actual de los cánones, de la disciplina, de los concordatos, especialmente españoles, y de varias disposiciones relativas al culto y clero; los usos de la corte de roma, la práctica y reglas de la cancilera romana; la jerarquía eclesiástica con los derechos y obligaciones de los miembros de cada grada, la policía exterior, la disciplina general de la Iglesia y la particular de la española y particularmente todo lo comprendido en el derecho canónico bajo los nombres de personas, cosas y juicios eclesiásticos, aumentado con adiciones y artículos nuevos, algunos importantísimos del Derecho canónico que tienen relación con la medicina legal o higiene pública, tales como aborto, infanticidio, inhumación, exhumación, hospital, cementerio, reuniones en las iglesias, etc. Madrid: Imprenta José de la Peña.

Berardi, Carlos Sebastián (1791). Instituciones del derecho eclesiástico. Madrid: viuda de Ibarra.

Ortiz Salcedo, Francisco (1764). Curia eclesiástica para secretarios de prelados, jueces eclesiásticos, y ordinarios, latinos y visitadores y Notarios Apostólicos, y de Visita. Madrid: Andrés Ramírez [Madrid, 1610].

Quiroga, Baltasar (1583). Constituciones Sinodales hechas por el Ilustrísimo y Reverendísimo Señor Don Gaspar de Quiroga, Cardenal de la Santa Iglesia de Roma, del título de Santa Balbina, Arzobispo de Toledo. Madrid: Francisco Sánchez. 